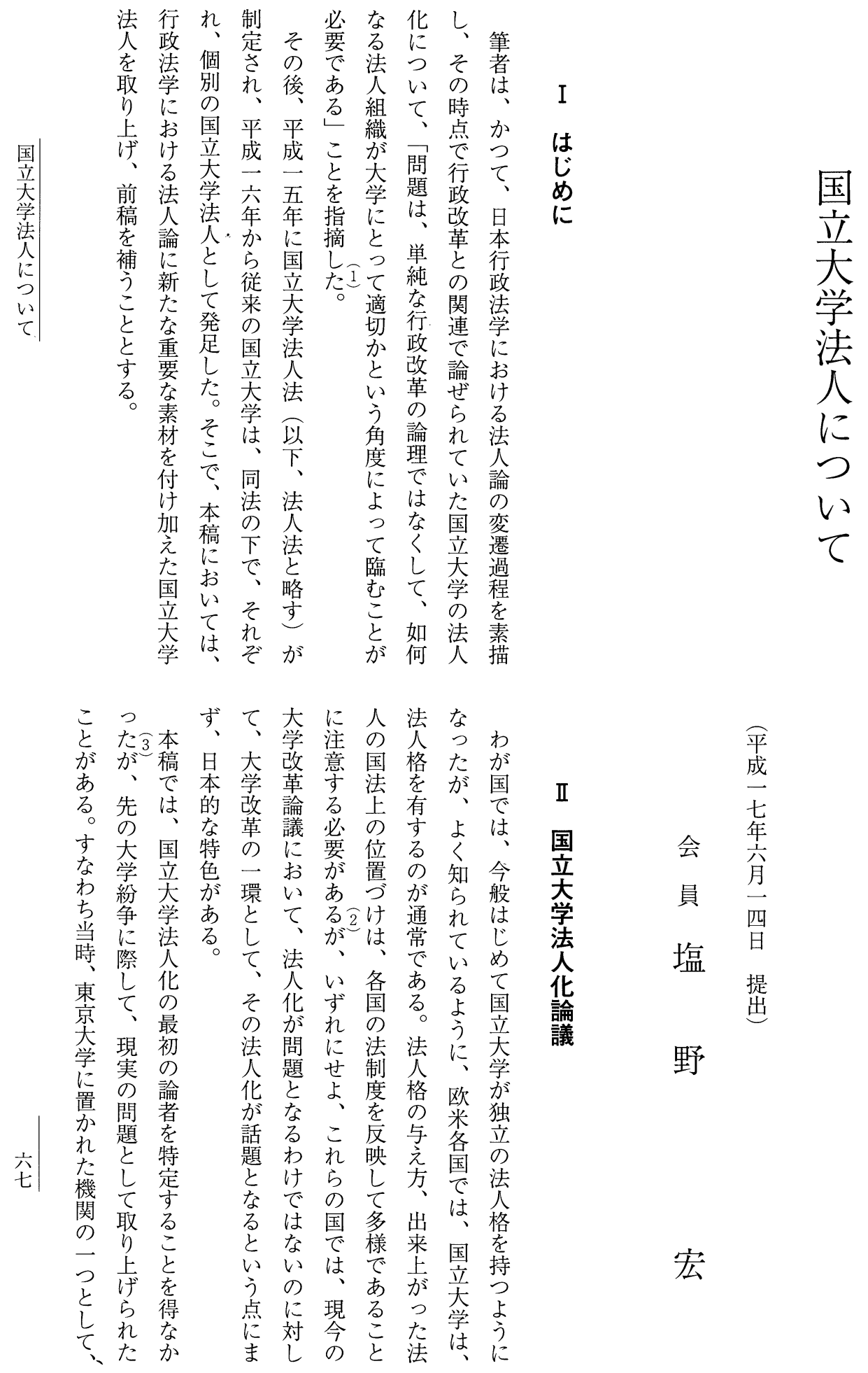



か見と設のは分じをのれ明把織想のる設国い会東

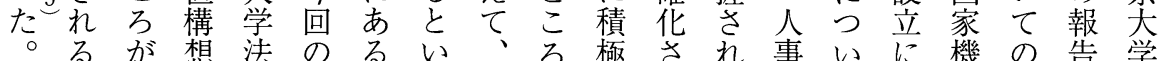
がなと人法とう独は的れ、坓提書.

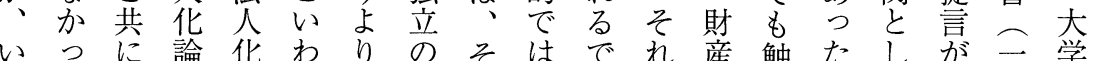
ずた忘はになは財のなあに管れがてな九改 れ。氺、現け、政大心ろ理、、、革 も去大赛れ合を部こうう等寺文れ○準 直のら学化ば理行分としての夲れ部て年備 ち後れ紛すな化うをもと、各学に省い三調 にも、争るららのこ国あし大方に妿にる。査

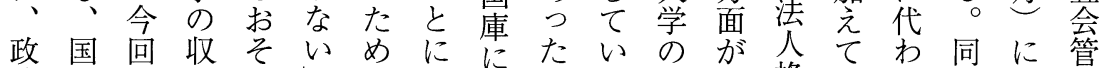
治立の縮れれのな頼。た権少格、る報お理 日法過がと合れ整々。限なが特行告い組 程学人程あい理ばざれた拉く与殊政のて織 にの化にるう化、うは法よとえ法委主、尃 登法論対がこの大を、文も゙ら人筫眼特門

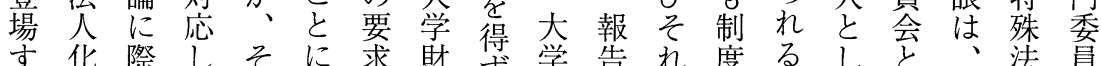

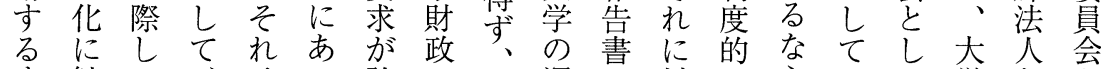
ま触て、はつ強の、運卓対にらのて学と命 でれも大とだま特大党は応はば大の行しあ にる省学も。方殊学資必守东学大政てり は文み委かこ危性が金ずる体大法学をの、

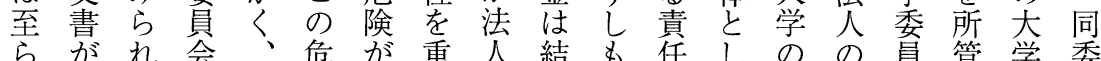
な散る合こ惧多ん格局こがて組構会导に䆩

と対法し の調新国国に、るけとも施般橋 变象人て現で香新立立飲しと狆い组策の本わ ると法い行あ検い亲みかいどう上の行内が 行な制る法る討い学学込しうも方に一政閣国

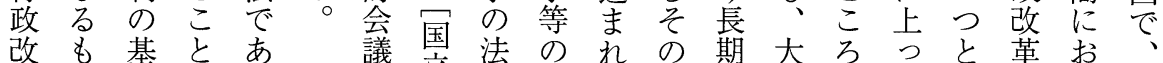
革の礎はる報立公独た後的学またしのけた

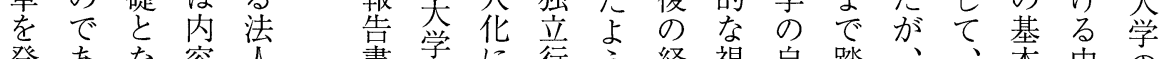
発あな容書学に行う経視自踏、独本中心 端るつ的法法向政な過野主み最独的央法 とがたに㤎し人法形はに性切終立卜省公 た報い明こ

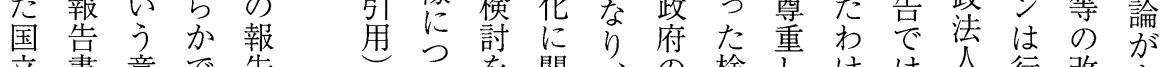

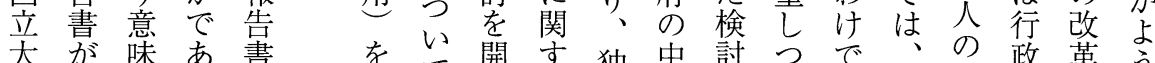

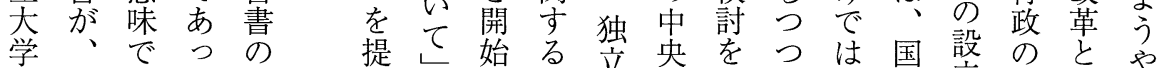

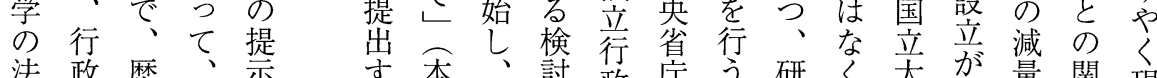
法政糜報示守本、討政序う研々夲が量関現

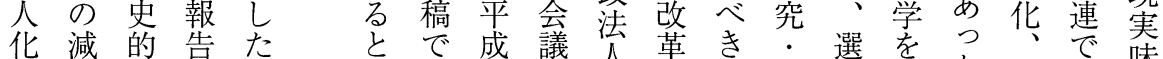
問量批がといは西㤎化と西教択独た効あ味

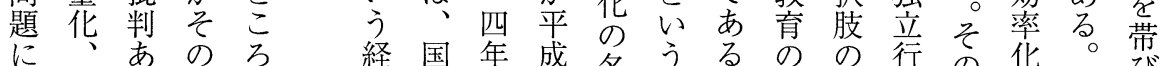
に関効る後に経国年成名うる可の行の化。等

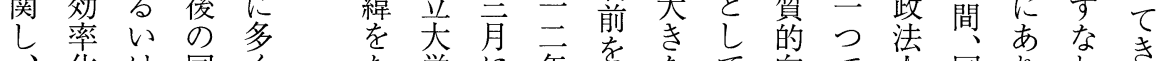

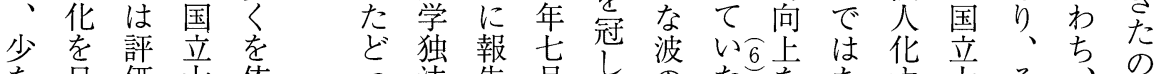

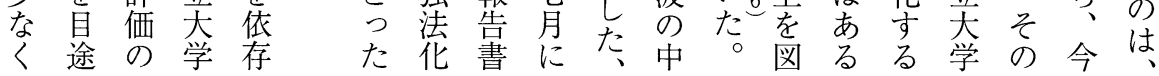



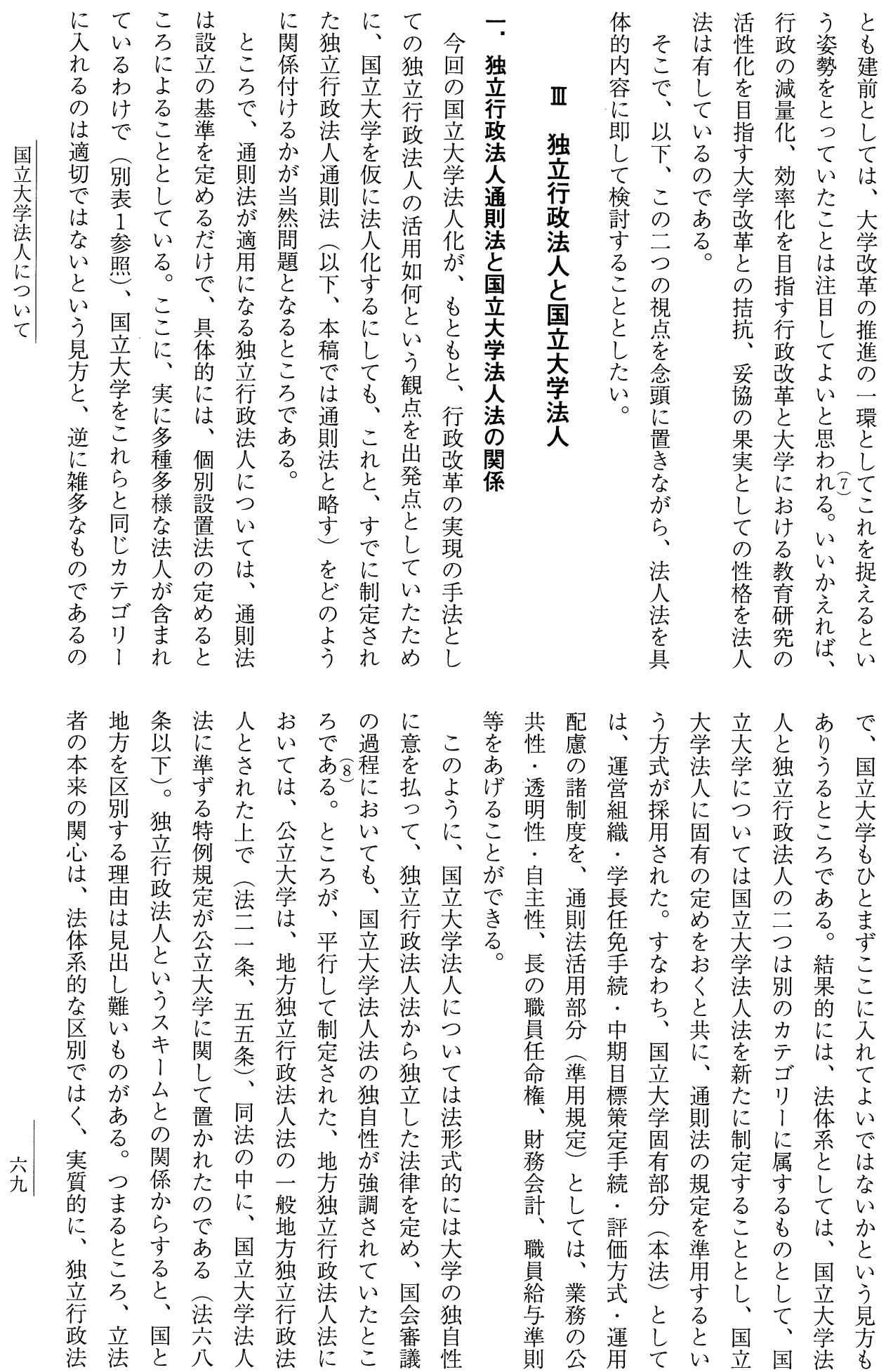
虺立行政法人一監（平成17年10月1日現在)

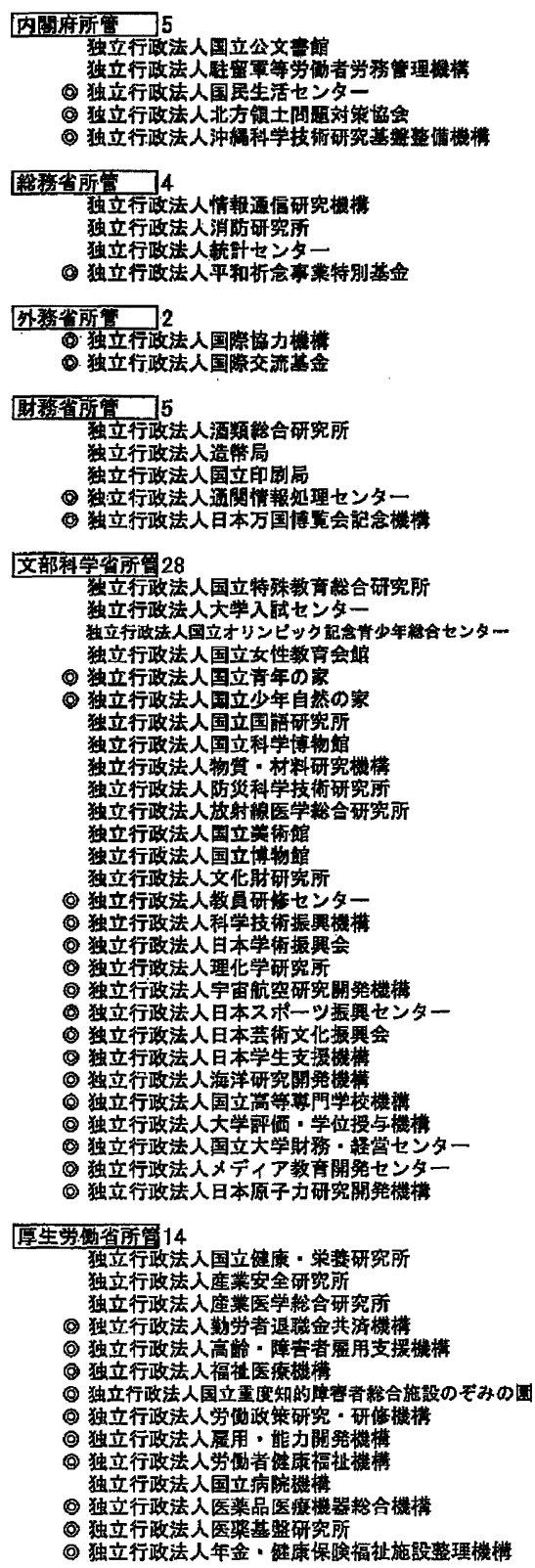

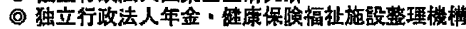

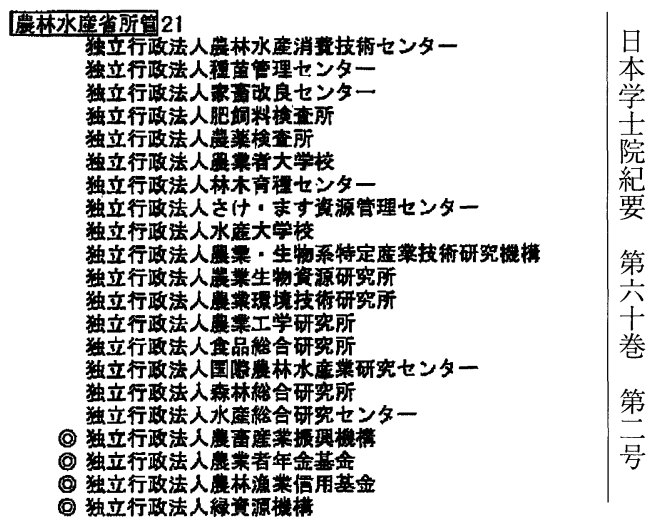

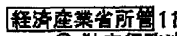

(9) 独立行政法人経済産菜研究所 独立行政法人工莱所有梅估势 - 研修斯

(2) 独立行政法人日本留思保險

(9) 独立行政法人重菜技街絞合研究所

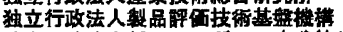

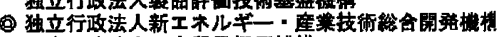

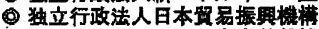

- 独立行政法人原子力安全基盤機䅦

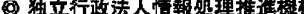

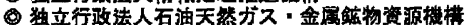

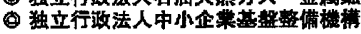

\section{国土交通省所兽21}

独立行政法人土木研究所

独立行政法人张管研究所

独立行政法人交通安全理境研究所

独立行政法人海上技街安全研究所

独立行政法人港湾空港技街研究所

独立行政法人雨子航法研究所

独立行政法人北海道開兴主木研究所

独立行政法人海技大学校

独立行政法人航海训结所

独立行政法人海胃学校

独立行政法人林空大学校 官動草梌套独立行政法人

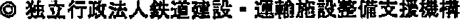

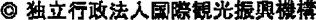

(2) 独立行政法入水資源推措

(9) 独立行政法人自到事事故刘策機楼

(9)独立行政法人空港周辺整供機棈

(2) 独立行政法入海上炎害防止センター

(9) 独立行政法入都市再生楼模

(ㅇ) 独立行政法人芘美群岛振興開発基金

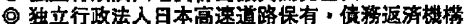

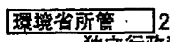

独立行政法人国立懪境䂨究所

- 独立行政法人䱜境再生保全機栍

合部 प13 法人

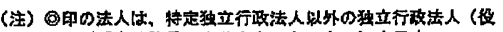

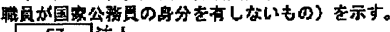
57 法人

※総務省ホームページより引用 


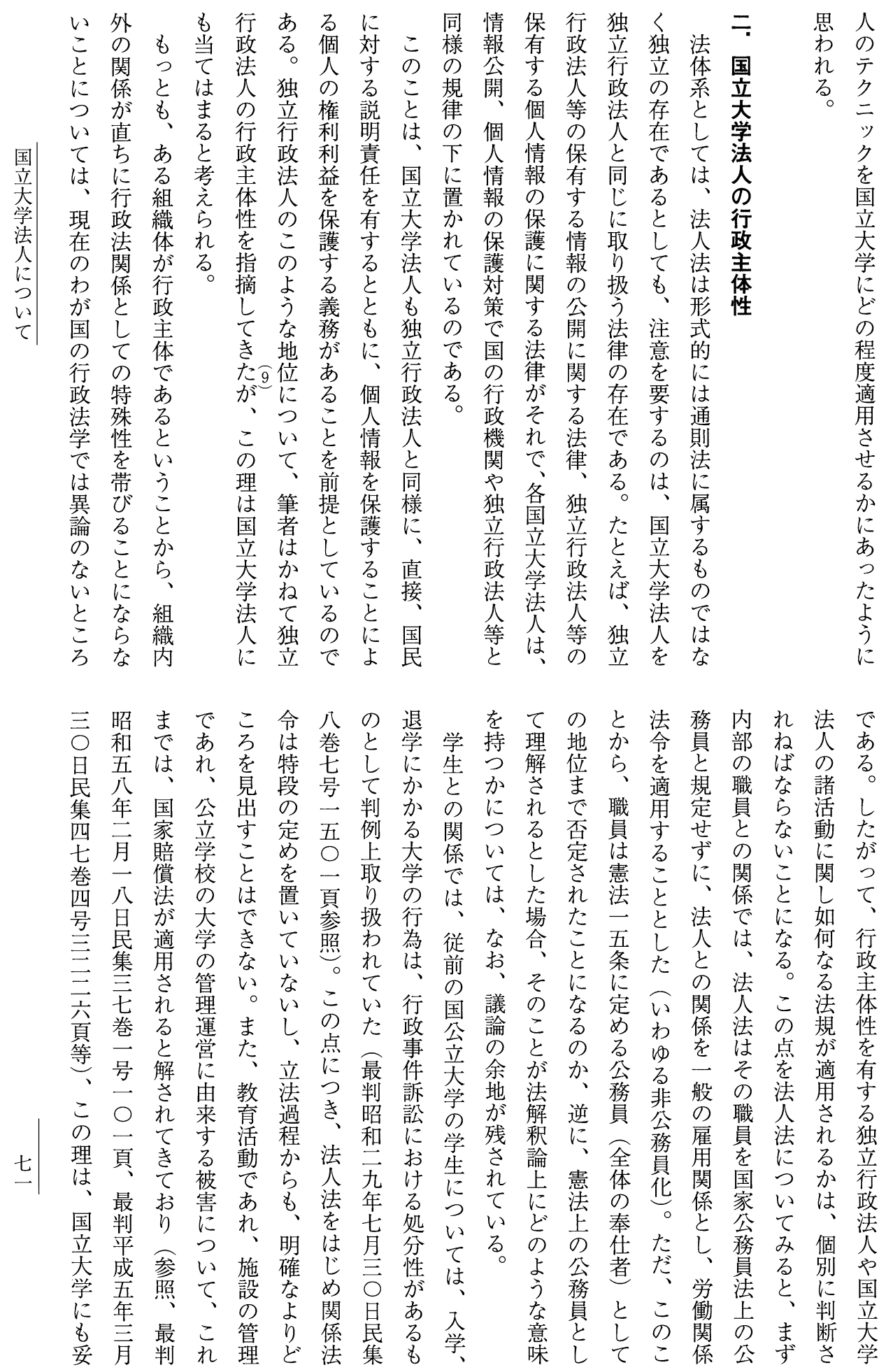



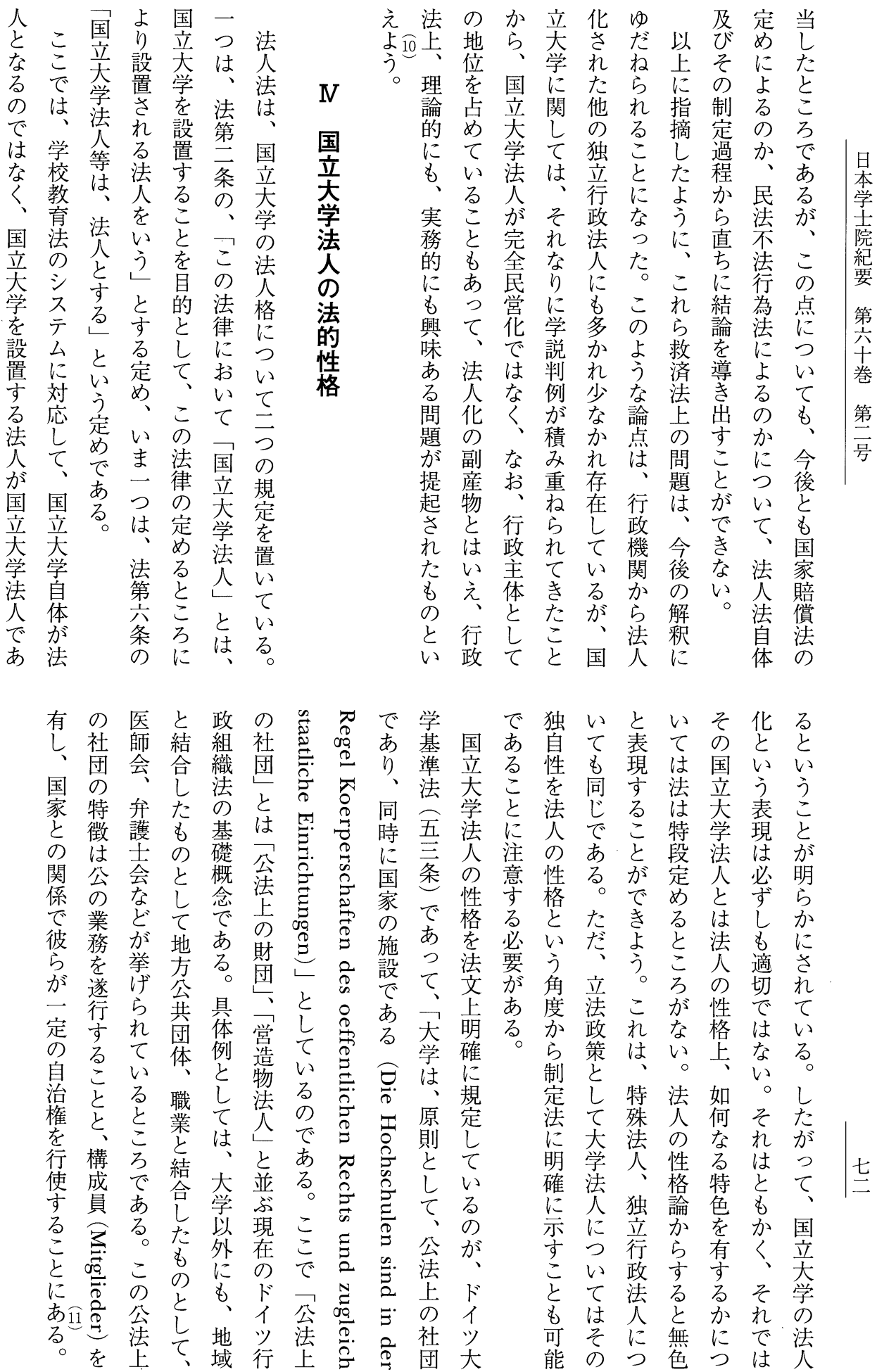


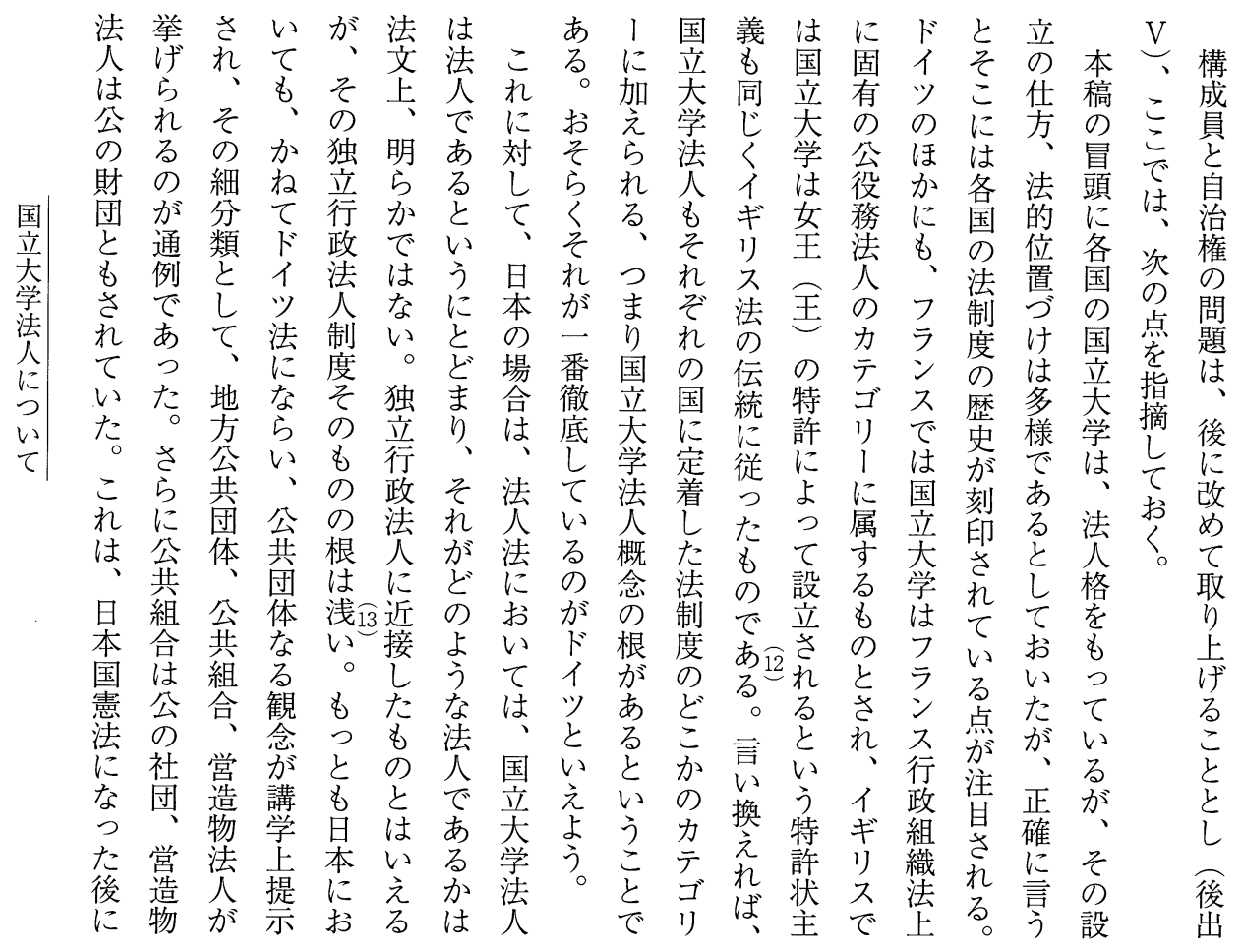

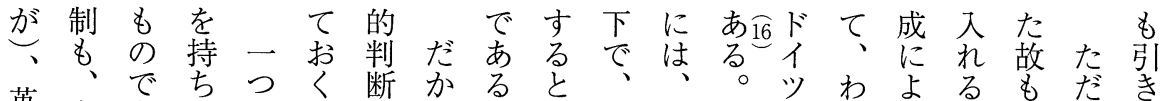

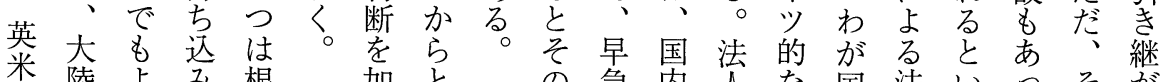

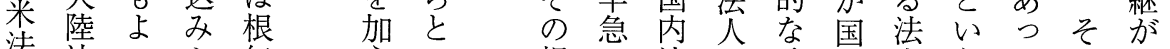
法法いや無尜い根の法の公の公うての视

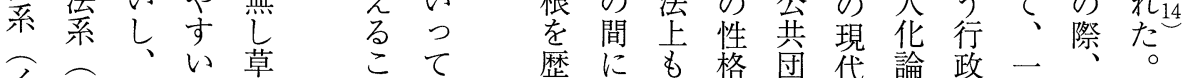

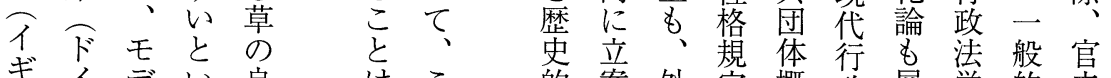
ギイデい良はこ的案外空概政展学的立

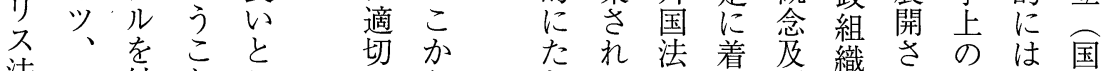

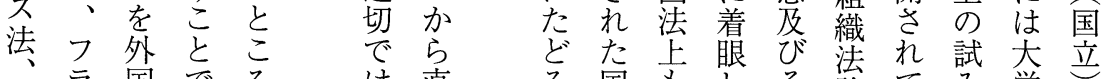

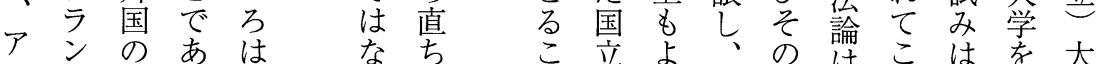

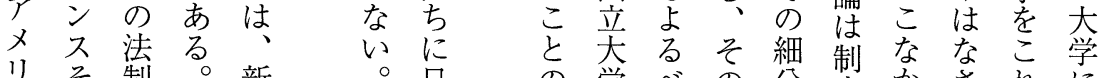

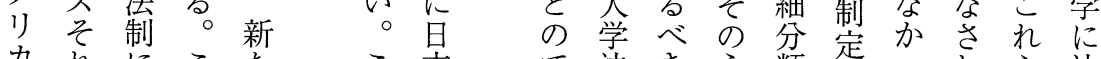
力れにこた本で法きう類法つれ足法

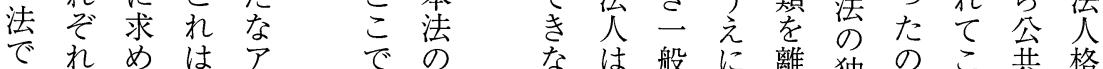

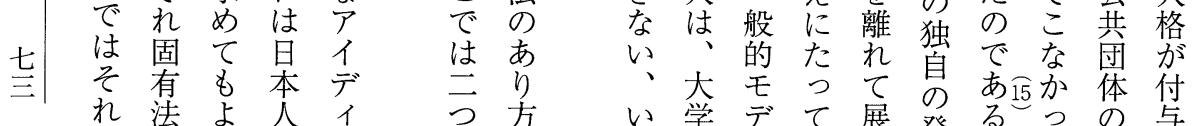

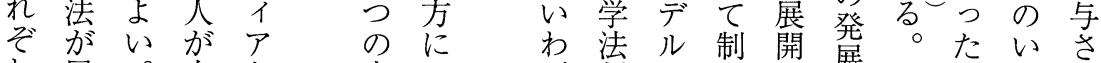
畓展る自な点つ制の度し展こしずれ 異開々 ら るて 外発法计、無点状築た応平団にな

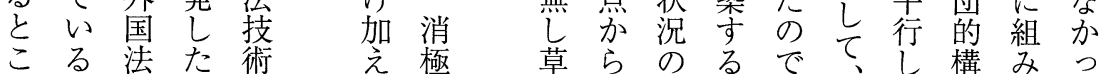



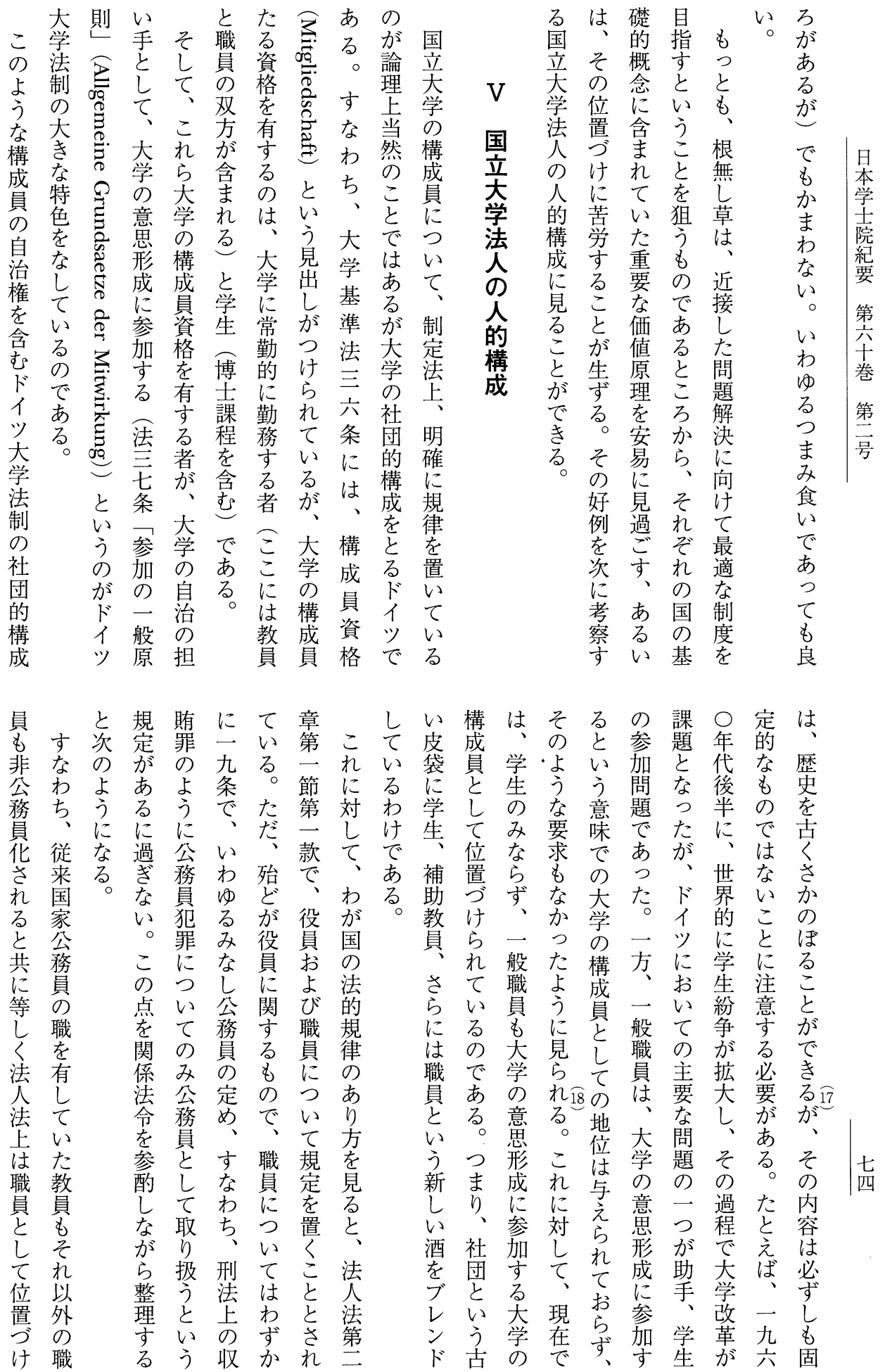
論こ社関が査はそれ法で対なこ号いれもら のこ会与、検十のて上学あしおたに拈にてれ

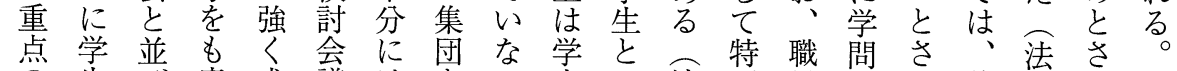
の生び意求議はをい生い法別員のれ後人れそ

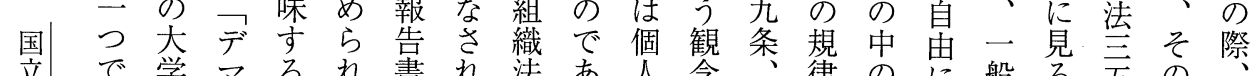

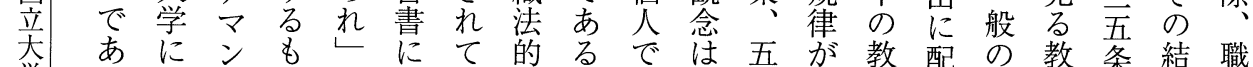

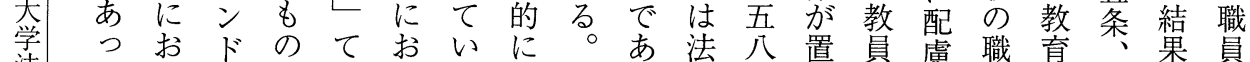

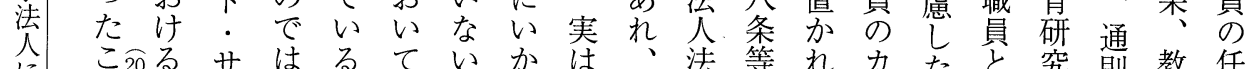

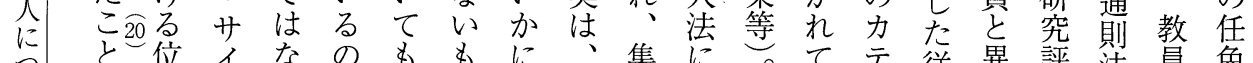
い方位 イ な の

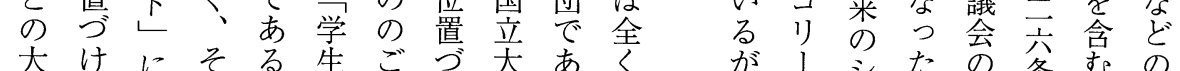

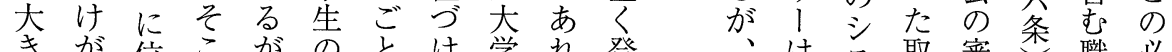

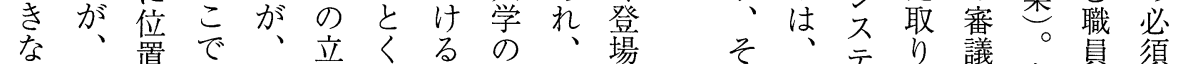

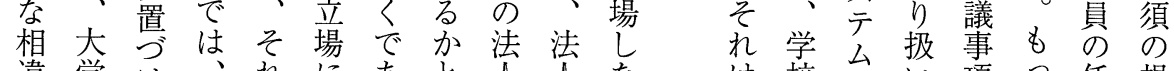

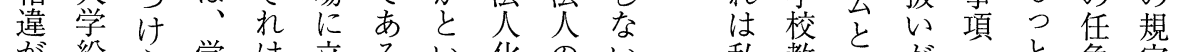
が紛ら学は立るい化のい私教のが䍃定

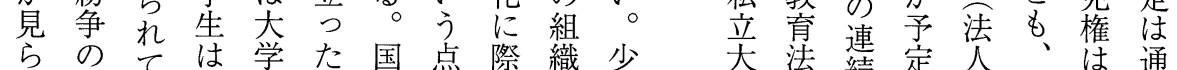
犯当い、運教立に采にな学に繶さ法教学則

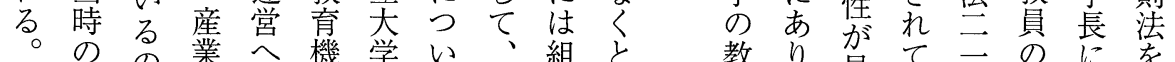
な大奆で界 の機学

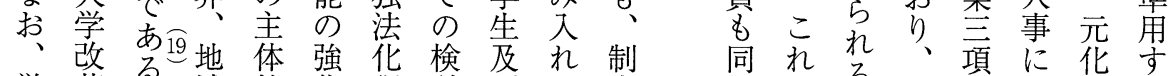
学革る。域的化調傠びら定様にる。こ隹う华す

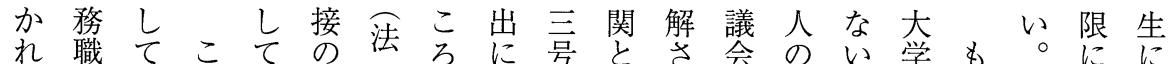

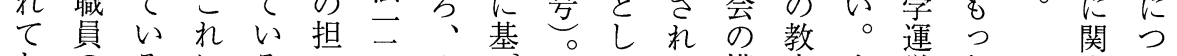

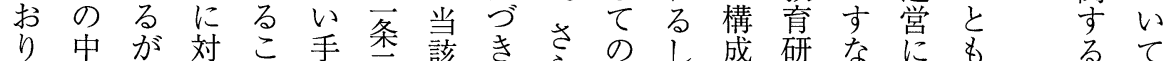

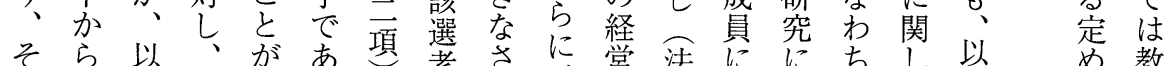

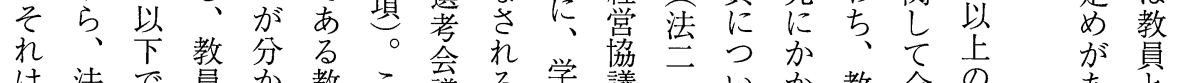

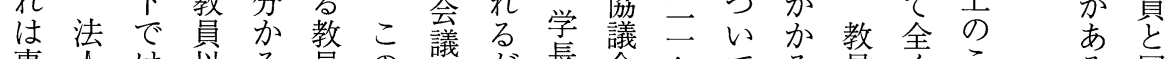

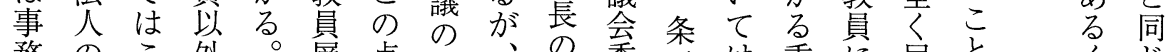

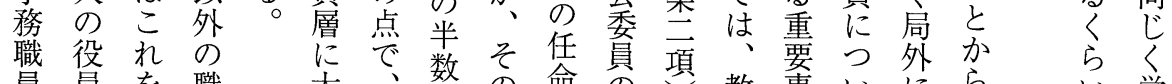
員員を職夺、数の命貝真教事いにら、学

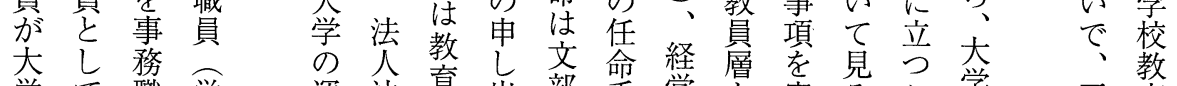

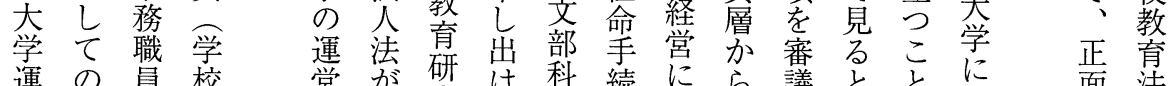

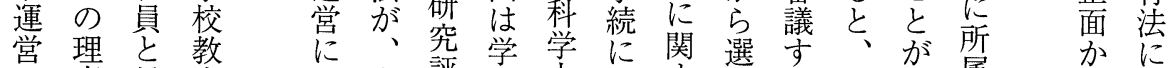

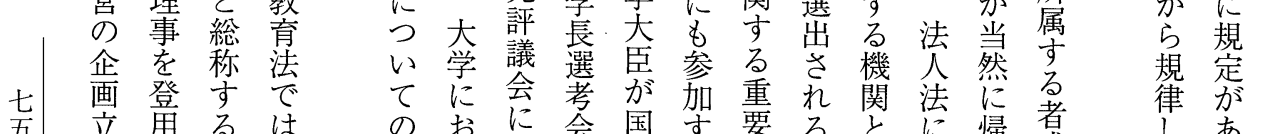

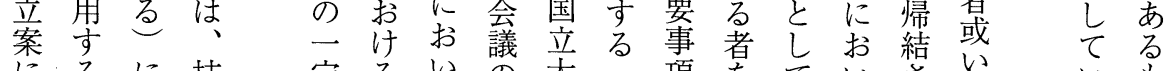

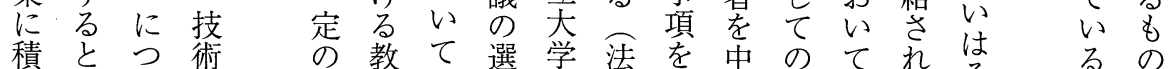

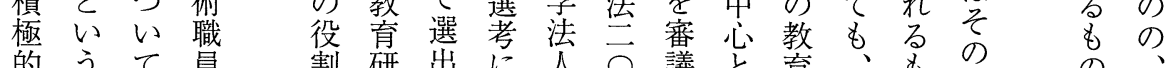

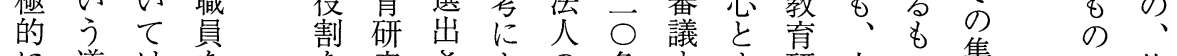
に道は学究さをの条すす研大の集で修

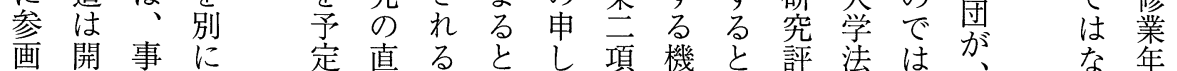




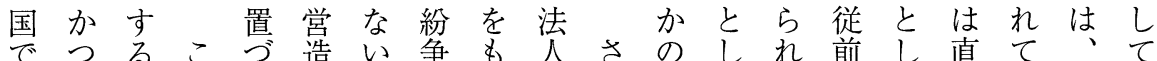
はて社のけ物ま当つ法ら閏てるるとて接い教い 社国的よ刺利に時て

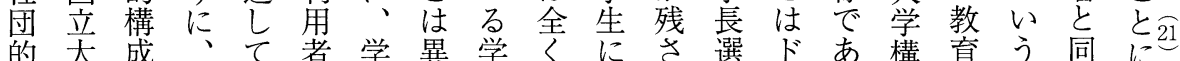
構学を少いに生な生存関れ考イる成・こじ正 成法読なるなはりに在して手ツ員研と齿

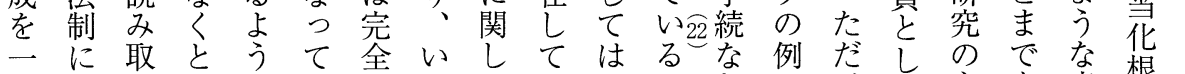

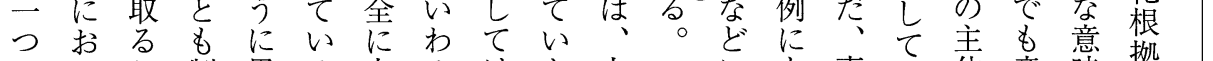

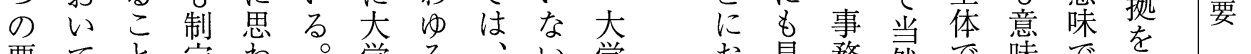
要てと定わ学るわ学摚務然で味でを見第

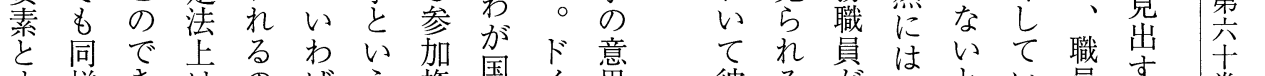

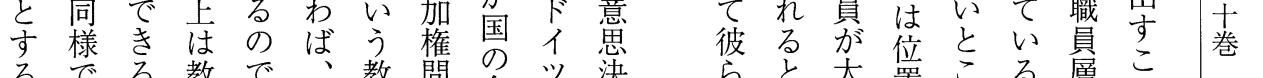

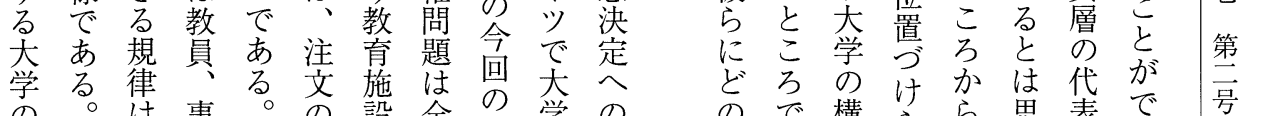
の。は事。多設全大学の の で構ら占思表で

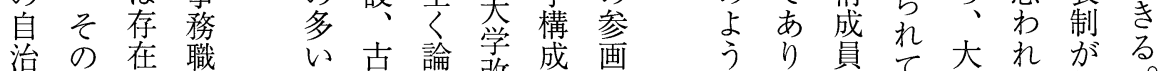

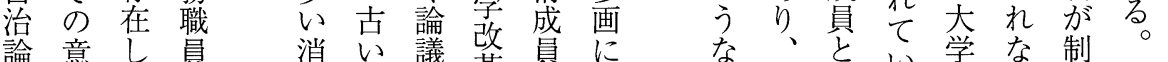

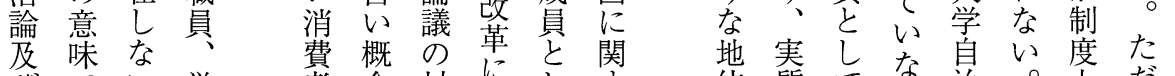

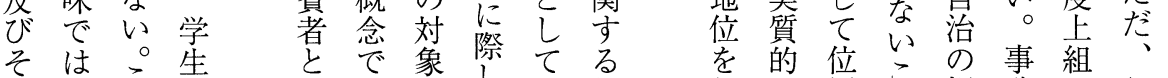

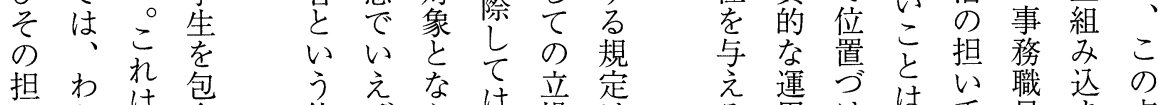

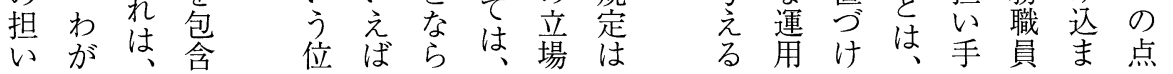

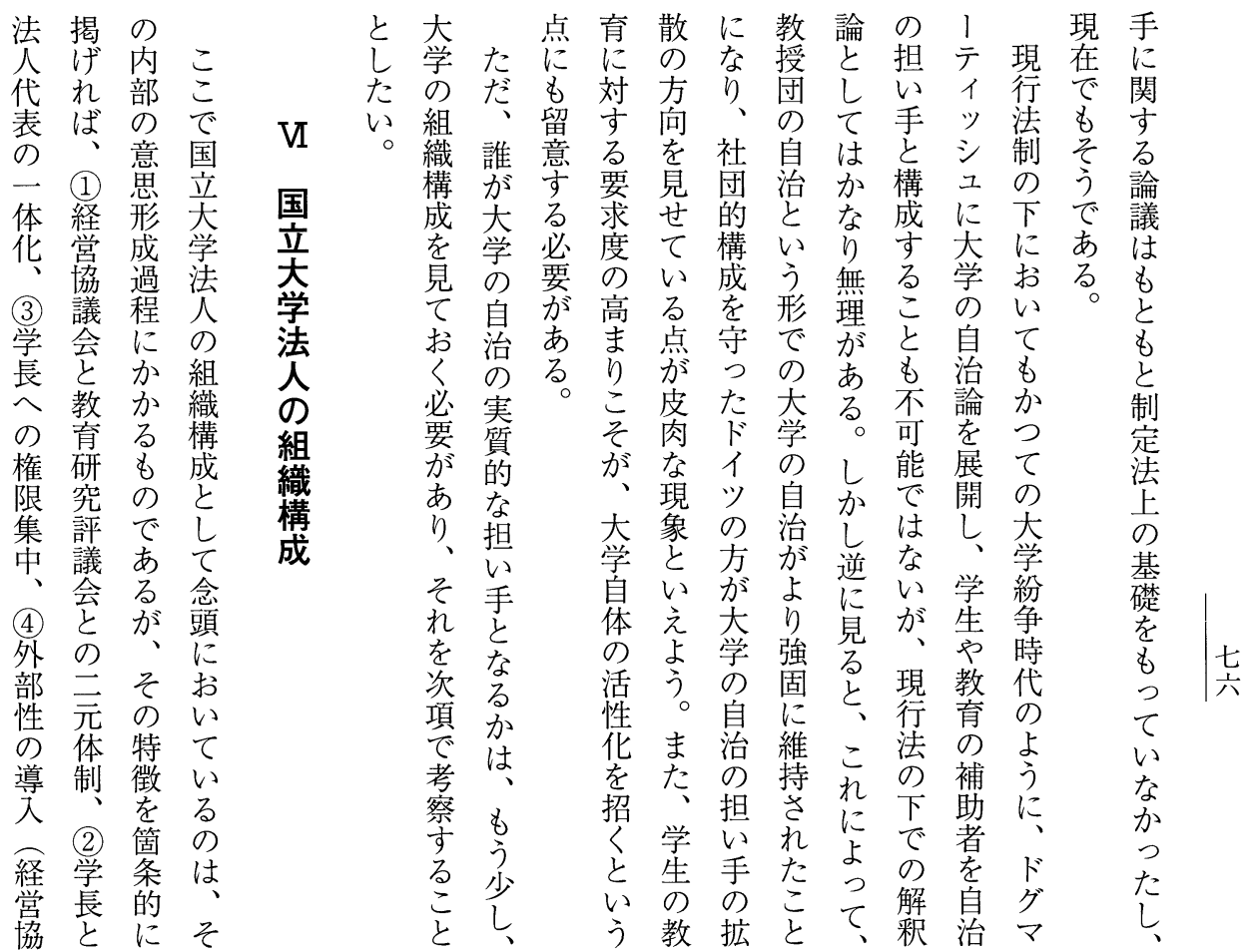




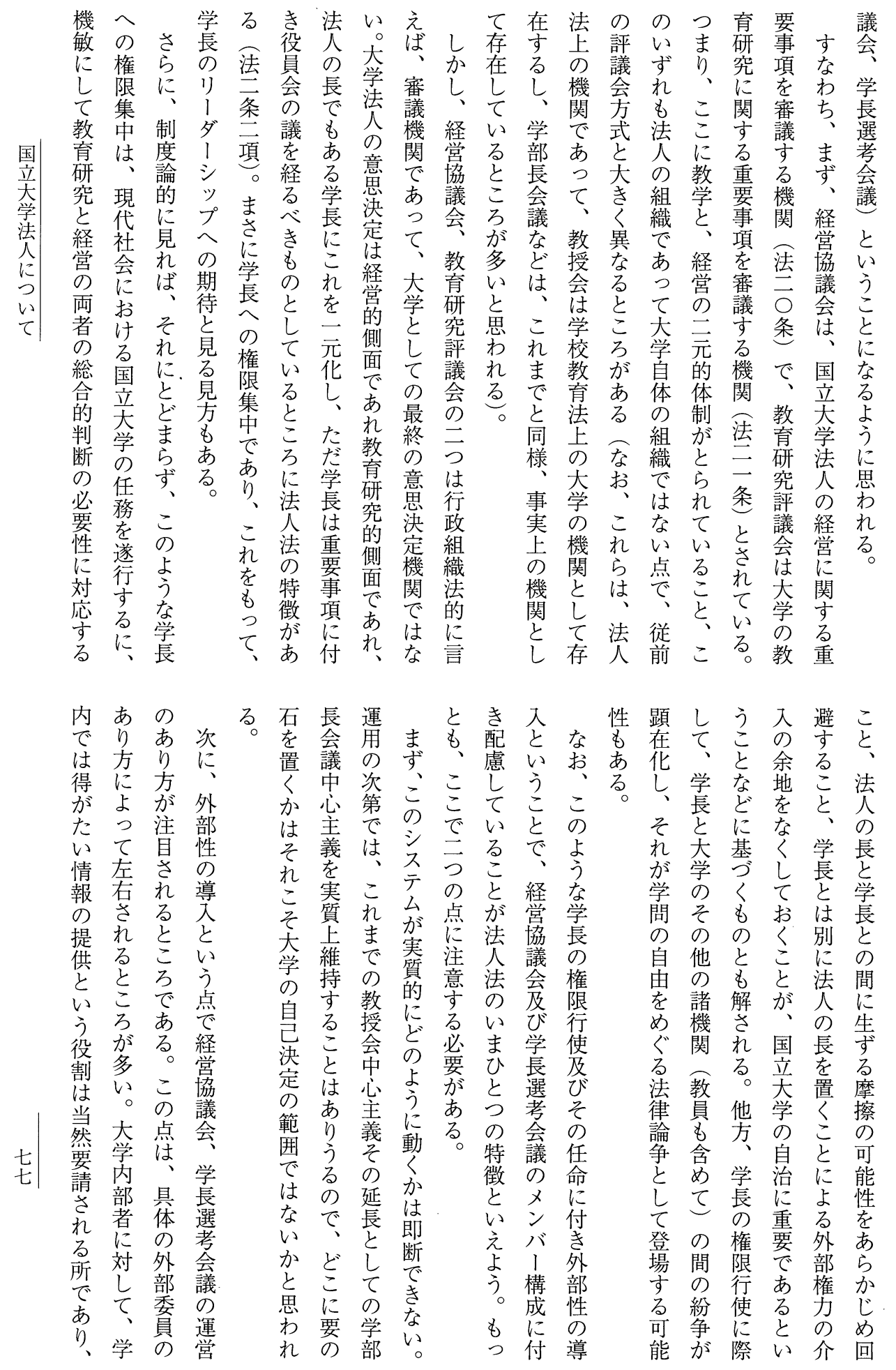




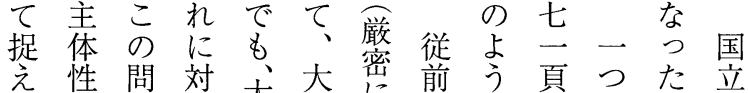

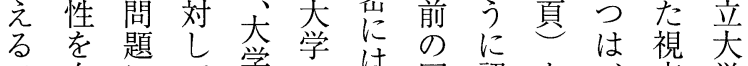
心有にて学先は国認を学学

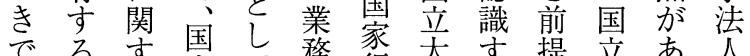

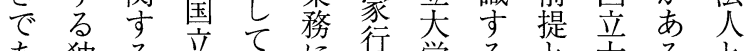

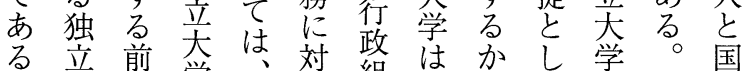
と立提学裁驽組国でた法架 考法条は判る織のあ法穴

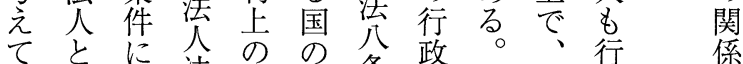
国係革法立卉定つ 立原多格道己劣施し

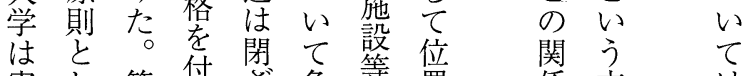

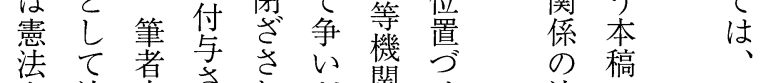
上法自れれが関け法の的い 大関はたて生した 学係行々た危たて 質前 か 自し行でこ 合ったた 心国大洼救行条政国政采

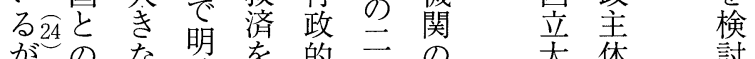
、関変確求関に一学学集討

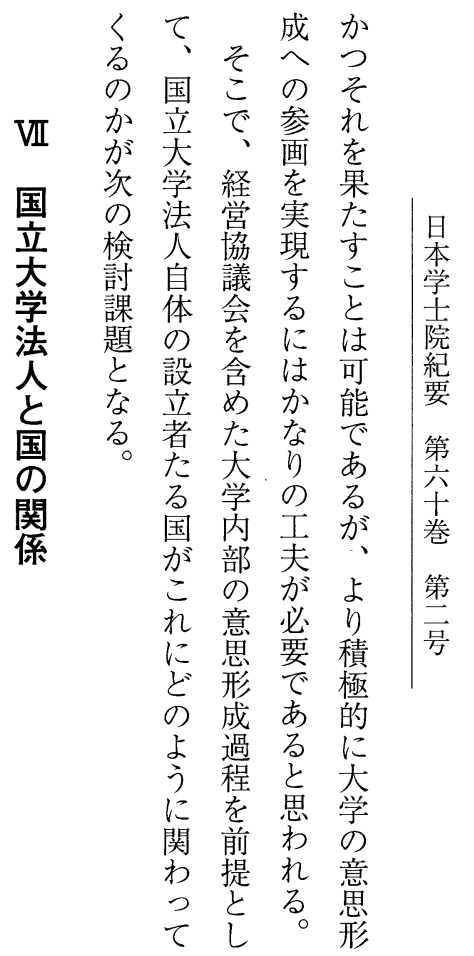
あ関な任次れ意律 洼いわ関い尔根関お国治

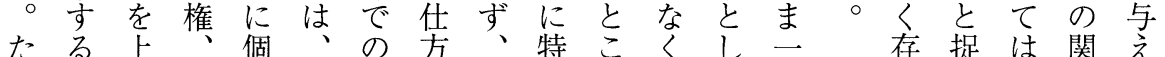

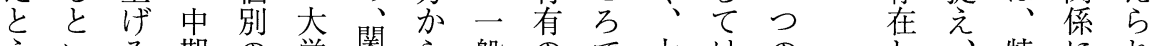

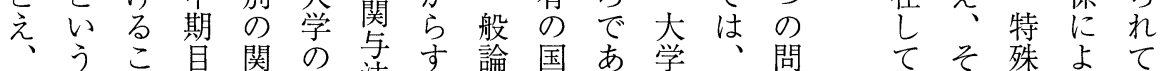

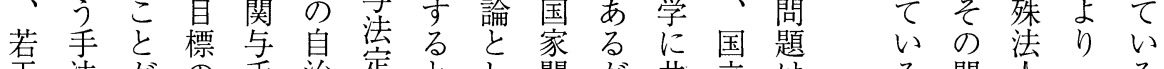
年法がの手治定と、関が共立は等間公一る

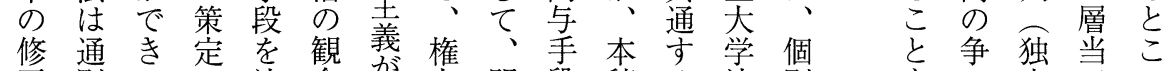

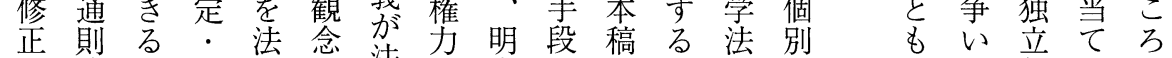
が法。中众に法的文がの国人関市に行はか なにこ期法適法関で問関の立与りつ政まら さおの計に合法与は題心監天法产き法るす

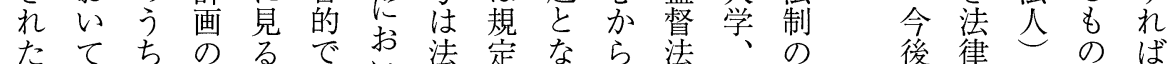

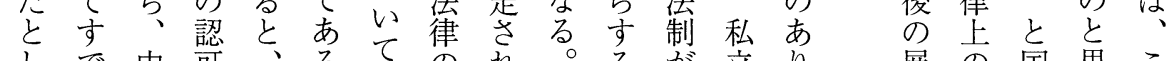
しで中可、るて採のれ根方立り展の国思こ てに期権主。畄根て と学大方開争と年の も採自要用拠い校学に訟の和理 、用標大な学をな教とつう注性関る。

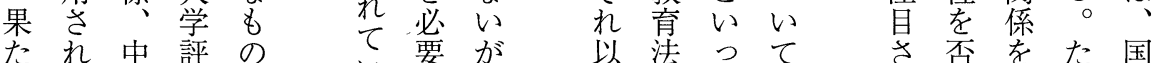
てて期価と権し る

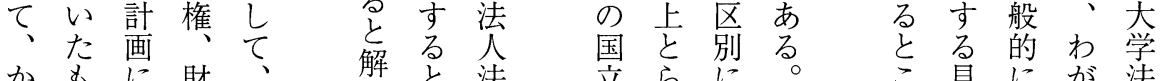
かも るでが権長柱う規学てかが 


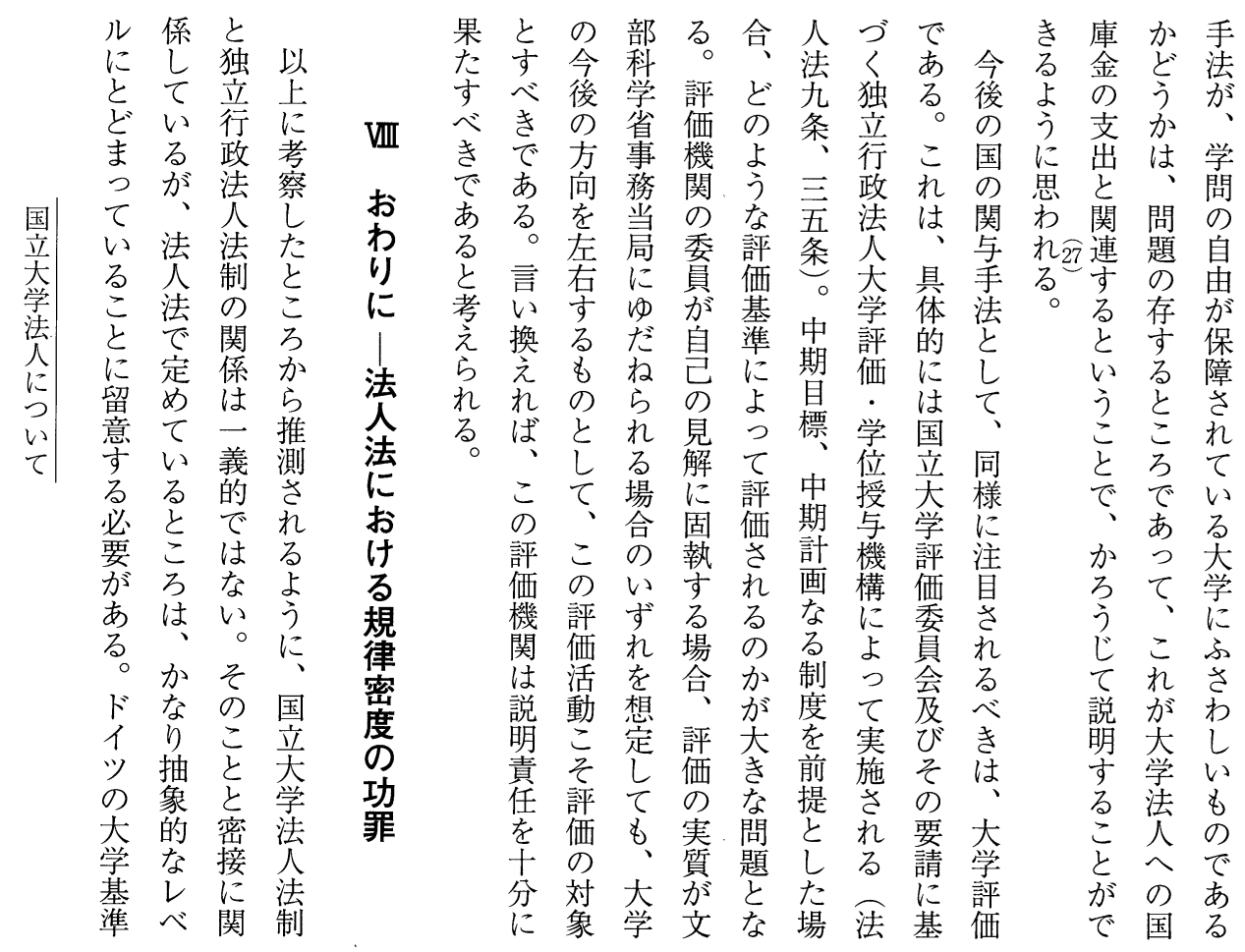

いくなと思大あ行けるの学な揮にで律れ法

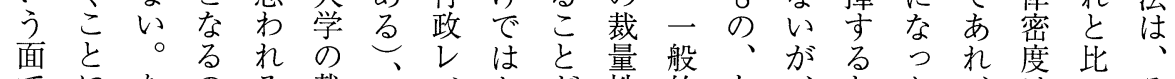

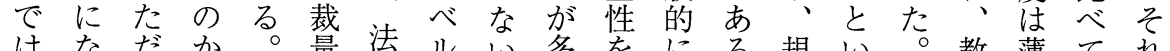
はな䄈量法ルい多をにる規い。教薄てれ

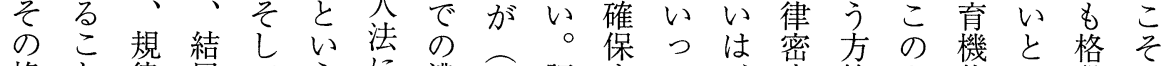

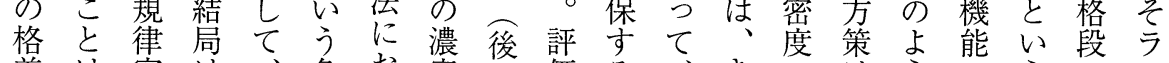

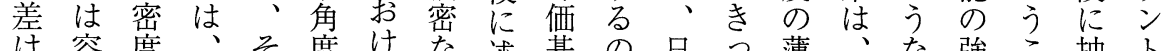

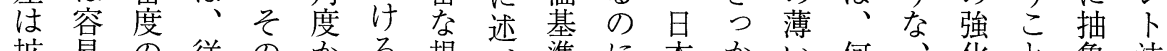
拡易の従のかる規心準に本か心何化と象法 大に薄前結ら賛律るの用のけ国も各でに的の し予さの果捉律密よ不い行を立法国あな的よ

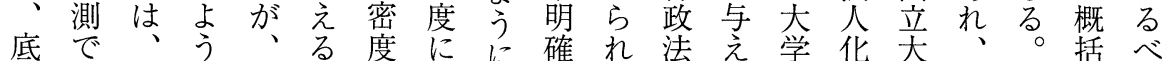
辺き当に大このょ性て規た法に学各経的き のる面横学と薄つ評ないはも众よが大営で基 ほ。並のの多て価どる規の法う横学点あ準

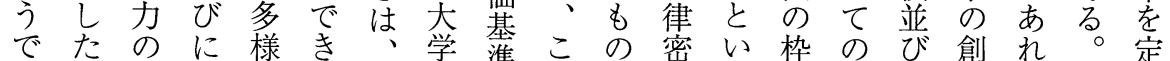
七はがあな华る行が淮のと度え組みで意代っ

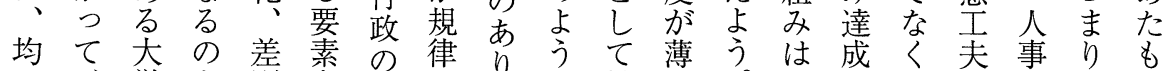

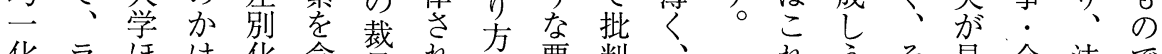
化ラほは华含量杂方要判、交うそ見会法で のンど、とん量る年素のそをるるのら計律あ 方キ有即いでは扔う文対れ促も個れ机にる

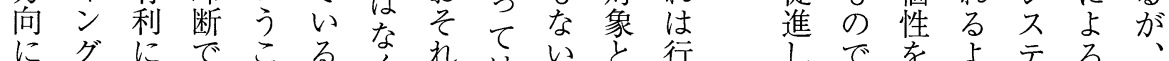

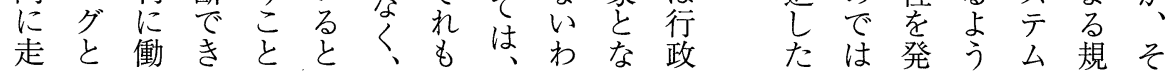




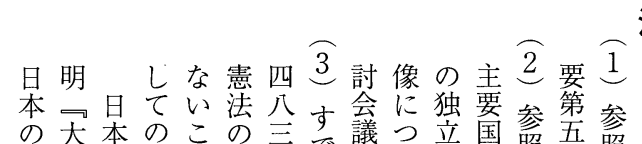
場学国指と下頁で議つ章国熊吾照 合の憲摘がでは心告て政扮国巻塩 法法は推も官美書法け竞第掹

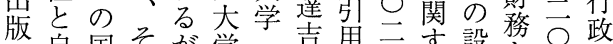

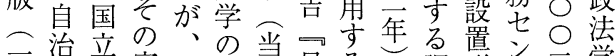

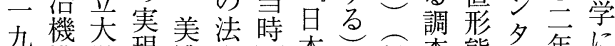
九構学現濃资照本查態多年に 八に法の部化営政○本詂管研五け 年関化言のが営跣九本淕管究九る 多化言指全造法貟稿会理報貟法 以る論は摘く物卷以で誐塤告页人 に究推い大議人、。国新些号諭 しドにのれに斐妾い方遷 江搪って二 そアは大た扔厹 れメ、のわり光 にリ高方け、辛 よカ木法で明公筒法学欧声 る. 英它は治年検人等采紀

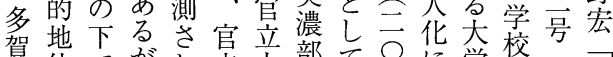

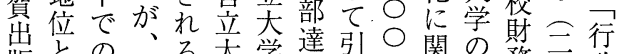

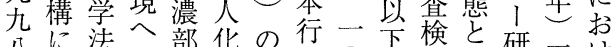
市研のなは論法巻卡は・財㫐論 詳|移。学さ化有国新六二恋

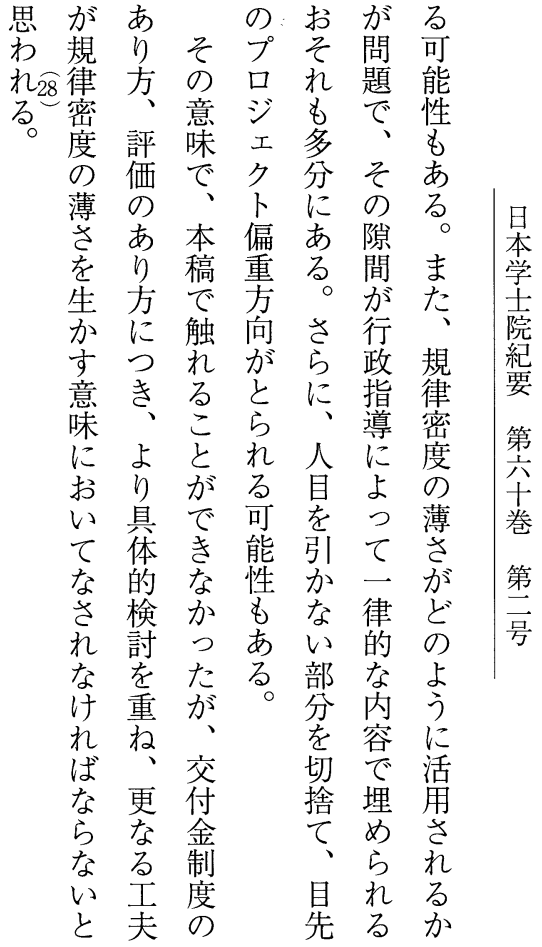

立る上設はでの通 $\widehat{8}$ 状小提に大改機 $\overparen{7}$ 三 $\widehat{6}$ る育 $\widehat{5}$ 委 $\overparen{4}$ 取と、 をいげ計ごこご法則政と早なと富学革能国二参が審国貝以り

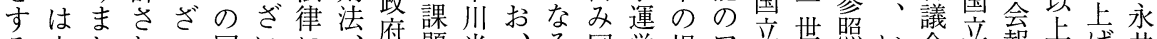
る中しれい国いに腐題光、る国営視ア立世照い会关報に代井 期たてま立ま基そ参䞥 4 郎同際点点ウ学紀行ず夿告にら道

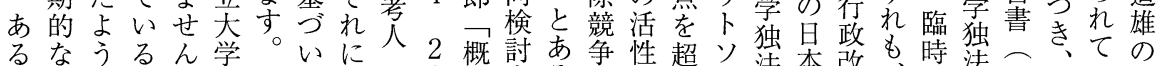

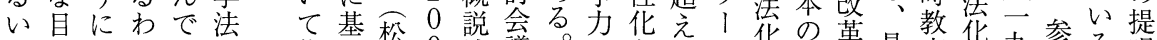

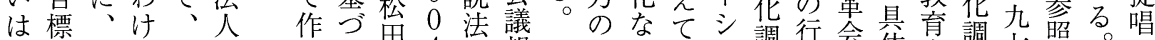

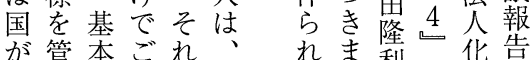
が管基ごれ、 財理的ざとそ 源をないはの 措す枠ま別独 置る組すの立 の、み。国行 義さ、制立政 務ら自度大法 付に主設学人 计々性計法通 をのやの人則 負前自内法法 弓提律容とに てと性はい基 いしを、うゔ るて与先こく

、のえほと個

そ国るどで別 うが、申制法 い設あし度で れま梨こ化告 るし君三経め げ各発四緯ぐる ざ別独年東立 心法立二京大 まと行二学学 す言政面編会 そて法以東界 れ抄毕東反 がり、参京応 独ま独照大等 立卞立。学に 行が行変? 政、政革て 法個法現は で各售四方国 あど、ン調行会体審調七照。に る、教グ査検報的議検年東架

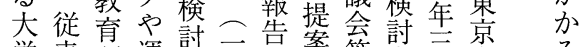
学来研運会古最案等会言尔る つか究営会九緼をで議月学 くらのの誐九報しの係報—. の大高効告年告い法告書

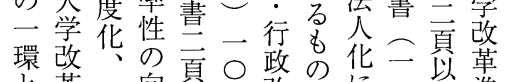
七流僼とこ頁会なれ頁な調 検れ㐙いこ議いる以查駆 す促なた問 る進学い題 とし、うわは、 が活く行行 前力萿 政政 と革個向に二改でに二年準 討をかっの事。提下会的

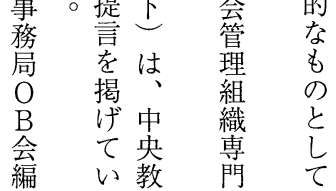


尺 $\overparen{11}$ のきのの校行要為処も関集立特の法別戒れ $\overparen{10}$ 参 $\overparen{9}$ 日度j 参有続設でに使国とに分国係竞を別では権行る私照㕵参設点 心昭無き置はかの家さた性有と二問権、国力為。梨䚑野議計で

8 は適管なか拡賠れけを財し巻わ力当公関等と見 宏院には 損の責のも的法と権め法制号い係に然竞係を処うれ 害対任での適の考力るの定三もには校唯分のれ 償象にで用適え性余適法罠の代国のにとは

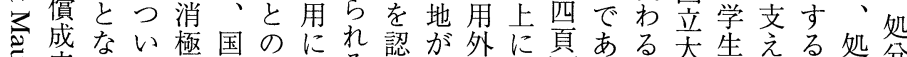
童るてに立関つる訫なに整、真近学生ら行分分

要とは解大係い吕るくな理国こ年法徒れ政性に

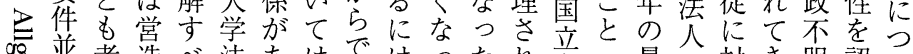
前恶考造へ法あはではったれ妾っ最の対き服認い る゙え物き人る市々たこた学参高学すた審めて 四ら概でのが判るれことこ法照裁生るも查るは 賠れ含あ行、例なとかと众、判生行の法徉は 償るにる為そにりから、の最所適為との来的 額。は○にれよ のら、そ職判の用を解定のを 算た包国ははる 悬た含家射、ー 定定賠程主 条 任国れ償がとに 関家る法当し定 气関賠こ完然てめ 它係償亡条に、る な法かのは国公

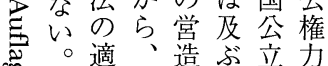
明す管の員昭部さ対さめ判否 確る理他に和分れ象れこ例定 なと行の対五秩々とるそは卞 制、為物禁云序るしがの、心 定学す的る年のすて、前学き 法生へ管関主法制行提生毛 のにて理係月理な定政とにの 根対ににが一はなさ不し対と 拠すつつ、五国しれ服て考 がるいい雇日公とた審のるえ 宏文な同 行教つビ 政嵙いで 法委るる 吕意とるる 会いけ 第会うで 二議こあ 版録とり 、三 ごま 有虽ざす 裔爾いれ 四ま頁市 ど 二頁守 平 制 年 成 度 年五 と 八年て

六は

頁別 怘適引造ぶ立力 必行てて用民私と无查特懲ら

以亲制

監 $\overparen{23}$ 下 $\overparen{22} \overparen{21}$ 二伊 $\overparen{20} \overparen{19}$ を一九 $\overparen{18}$ 七 。 $\overparen{17}$ 照 $\overparen{16}$ 位官 $\overparen{15}$ 訂四 $\overparen{14}$ 以 $\overparen{13} \overparen{12}$

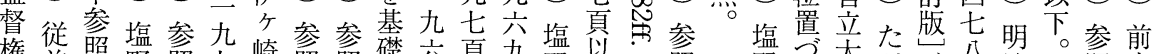

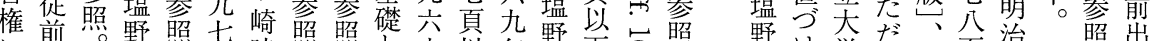

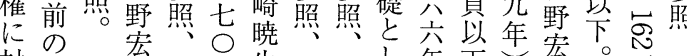
対国宏国年生東国し年下宏

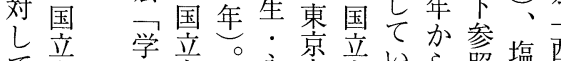

妾学竎。永亲妾心占照塩西 裁学選学等学学艻。野イ

判は考独憲改独九な宏不

上行制法

に政度化

う関 I 查

こで D 検

一革法交挍行大

編 準 化

$\neg$ 備 調

公之政学

大 調 查

年こ政学

学 査 検

はあ 西会

機た七議

関

の会討ド文法の

自報 会

治告議

訴で韋告

八

訟

イ は筆諸事

学 告滞 品題

生一畫在 フ尔

しン有卫

地六頁

当立 $\quad$ 四

位 年

たボ斐り

た学

○頁

もに五

際儿閣 ス

収桨二四

II 五

の 対

集学三主

た生 ○公

成 頁

$\begin{array}{ll}\text { とる } & \text { 九 } \\ \text { て国 頁 }\end{array}$

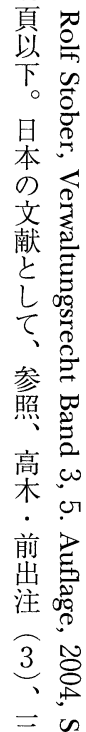

刃

野学た有頁涪

前てに、韭以憲

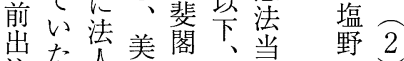

下。注气格濃こ日時

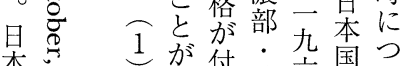

の 注与前六憲き

前 所

出揭

注 の

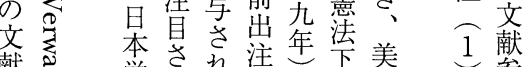

資料年

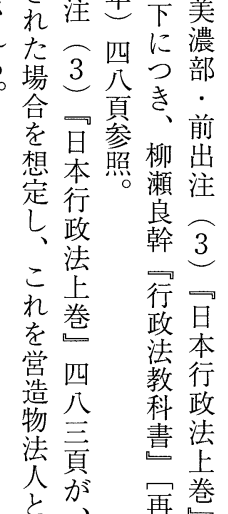

日照

参气

3 용

三 n 


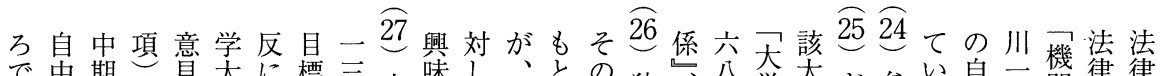

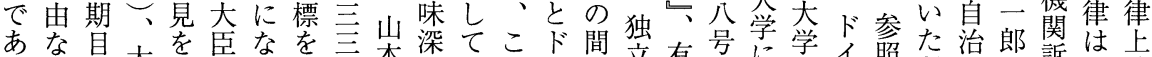

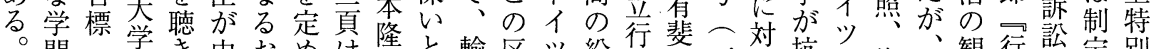

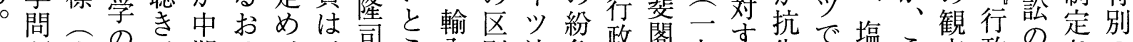
研兵特、期々、、可こ入別法争政九会九增こ点政のさの

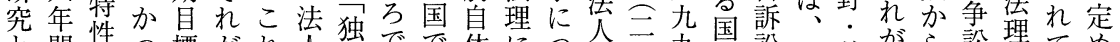

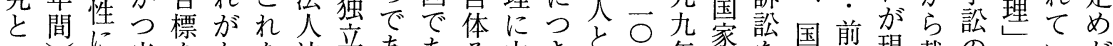
いに当をあを法行ああそ由き国○年関を立出現裁の法いが うなる該定る国制政るるの来法国○祭提妾乼実判理法なな

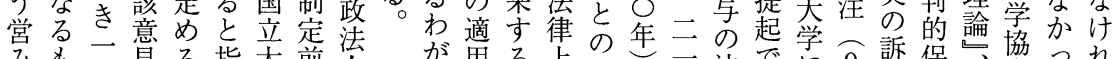

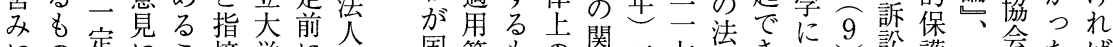
にの定見导摘学に会 適を配配とし法 設配慮とて台通ジ て定慮昰しいに則沓 い守をるたた指法り

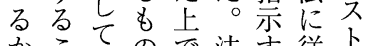
加こので法守従卜 どととと全るい二 方息。賛事法と文六 ががし定前にい文六 問尔名国いこ䇆号 題大六立てと学二 と学も法夿はは大亏 なにと言学、音臣方 と忖条人部罣中吾 国範もの関三七律き対謑護有会たば

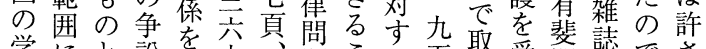
学にと訟外六題こる五取受閣誌でさ 説つ解性部頁山起と国頁占け焦古れ がきさ考部畋本明は家以步得二九る。゙ 頑柔れ否法下隆治委監下。号九巻。 な軟る定対参司学で督。杂き公第こ察 対なが展る年照行陾に異洼た能年分点上 応開母方政丵論監々性号学に

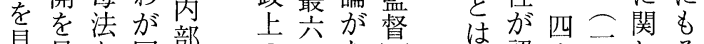
見見た国部の言な悲な認六九圥 せせるの染主至いに少め七七ての

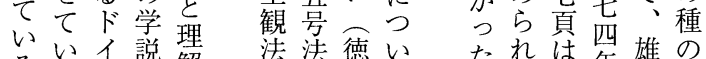
いいイ説解法法德いたれは年雄の るるツは解学本て 。る。年川特

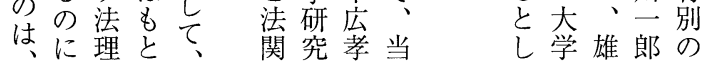


and national university corporations. The National University Corporations Law is silent on this point. The generally accepted view in Japan is that even if an administrative entity has the status of an independent juridical person, the relationship between administrative entities and the national government is fundamentally an internal one. On this reasoning, the relationship between the national government and a national university corporation is likewise internal, so a national university corporation would be precluded, for example, from seeking a judicial remedy for the government's illegal exercise of supervisory power. There has never been a judicial decision concerning this point. However, in my opinion, national university corporations are protected by the guarantee of university autonomy provided in Article 23 of the Constitution of Japan, so if an exercise of supervisory power by the national government infringes on university autonomy, national university corporations should be allowed to seek judicial relief.

The National University Corporations Law defines only the general outlines of university structure and of national government involvement; many points are left to operational discretion. This type of nonspecific statute is typical of Japanese administrative legislation. This lack of regulatory particularity is often criticized in Japan as leading to the unreasonable exercise of administrative discretion, a criticism that on the whole is justified. However, with regard to the legal structure of universities, that very lack of regulatory particularity has its advantages: it may allow national university corporations a sphere of freedom of action consistent with the principle of university autonomy. If national university corporations avail themselves of this latitude, it may promote healthy competition among universities, and lead to a welcome diversity in higher education. However, one must always be on guard against the danger that the Ministry of Education and Science might reassert Japan's traditional regulatory style, employing the law's lack of particularity to engage in discretionary intrusions into university affairs. 
university corporation, established under the National University Corporations Law, have the status of administrative entities, just as the independent administrative institutes do. Accordingly, national university corporations are likewise subject, for example, to the Law concerning Access to Information Held by Independent Administrative Institutes.

Under German civil law, as well as its Japanese counterpart modeled after it, there is a distinction between corporate juridical persons and foundations. Corresponding to this distinction, in administrative law as well there is dichotomy between public corporate juridical persons and public foundations. Premised on this dichotomy, German universities are legally characterized as public corporate juridical persons (Körperschaft des öffentlichen Rechts) composed of an association of the teaching staff, the clerical staff, and the students. By contrast, the National University Corporations Law makes no reference to this traditional classification. Furthermore, the new organizational structure departs from the traditional associational model; both the teaching staff and the clerical staff are considered employees, whereas the students are in the separate category of users of university facilities. The only special privileges accorded the teaching staff are representation on important committees such as education and research councils and committees to select candidates for the university presidency.

The traditional European understanding of universities as collective entities in which all members participate in decisionmaking has thus been rejected in Japan. While the power of the university president, chosen by selection committee, has been strengthened, we have likewise rejected the approach of state universities in the U.S. of concentrating power in the university's board of trustees.

Japan historically has adapted European and American systems for its own use, but only in part. We have selected those aspects suited to our society, and reconstructed them in a Japanese way. The National University Corporations Law is one more example of that long history.

The national university is a species of administrative entity. This raises a question about the nature of the relationship between the national government 


\title{
On National University Corporations
}

\author{
Hiroshi SHIONO, M. J. A.
}

National universities in Japan, since their establishment under the Meiji Constitution, have been defined as administrative organs of the Ministry of Education or the Ministry of Education and Science. However, the National University Corporations Law of 2002 changed that structure. Effective April 2004, all national universities have been recharacterized as National University Corporations.

This paper aims at analyzing a major change in the legal structure of Japanese university education: the National University Corporations Law.

The National University Corporations Law was enacted as part Japan's recent series of administrative reforms. One aspect of these administrative reforms was to establish independent administrative institutes, modeled on British administrative agencies. (See my article,"The Transition of Theories on Corporations in Administrative Law," in Transactions of the Japan Academy, vol. 56, no. 2.) Some proponents of administrative reform in Japan favored applying this model to national universities. Others viewed the model as inconsistent with the universities' purposes of education and research, and with the philosophy of autonomy of institutions of higher learning. Eventually, the government enacted two separate laws: the National University Corporations Law and the Uniform Law Concerning Independent Administrative Institutes, a law aimed at belttightening and streamlining the agencies. However, the latter law's efficiency orientation is reflected in the National University Corporations Law, which seeks to strongly improve efficiency in university administration.

The many private universities in Japan were established by "school corporations" under the Private Schools Law. By contrast, each national 